\title{
Virus - Mens
}

Citation for published version (APA):

Bruggeman, C. A. M. V. A. (1994). Virus - Mens: een spannende relatie. Datawyse / Universitaire Pers Maastricht. https://doi.org/10.26481/spe.19940923cb

Document status and date:

Published: 23/09/1994

DOI:

10.26481/spe.19940923cb

Document Version:

Publisher's PDF, also known as Version of record

\section{Please check the document version of this publication:}

- A submitted manuscript is the version of the article upon submission and before peer-review. There can be important differences between the submitted version and the official published version of record.

People interested in the research are advised to contact the author for the final version of the publication, or visit the DOI to the publisher's website.

- The final author version and the galley proof are versions of the publication after peer review.

- The final published version features the final layout of the paper including the volume, issue and page numbers.

Link to publication

\footnotetext{
General rights rights.

- You may freely distribute the URL identifying the publication in the public portal. please follow below link for the End User Agreement:

www.umlib.nl/taverne-license

Take down policy

If you believe that this document breaches copyright please contact us at:

repository@maastrichtuniversity.nl

providing details and we will investigate your claim.
}

Copyright and moral rights for the publications made accessible in the public portal are retained by the authors and/or other copyright owners and it is a condition of accessing publications that users recognise and abide by the legal requirements associated with these

- Users may download and print one copy of any publication from the public portal for the purpose of private study or research.

- You may not further distribute the material or use it for any profit-making activity or commercial gain

If the publication is distributed under the terms of Article $25 \mathrm{fa}$ of the Dutch Copyright Act, indicated by the "Taverne" license above, 


\section{Universiteitsbibilotheek}

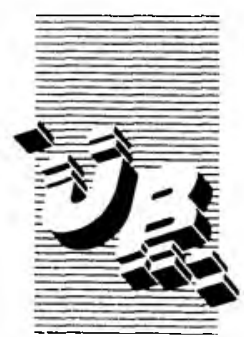

De uilleentermijn verstrijkt op:

\section{-3 NOT 39g}

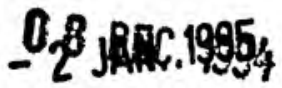

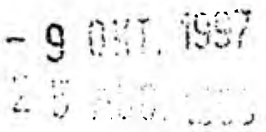

$27 \cdots \cdots$

Rilksuniversitert Limburg

Postbus 616

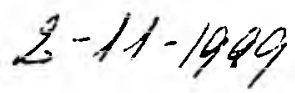

6200 MD Maastricht

Gelieve deze publicatie tijdig te retourneren of (telefonisch) verlenging van de vitleentermijn aan te vragen.

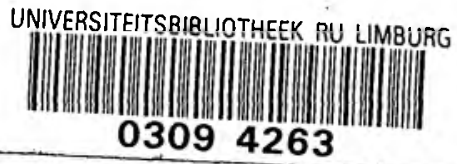




\section{VIRUS - MENS \\ EEN SPANNENDE RELATIE}

\section{REDE}

in verkorte vorm uitgesproken bij de aanvaarding van het ambt van hoogleraar in de Medische Microbiologie,

in het bijzonder de Virologie,

aan de Rijksuniversiteit Limburg

op vrijdag, 23 september 1994

door

Dr. C.A. BRUGGEMAN

UPM

UNIVERSITAIRE PERS MAASTRICHT 


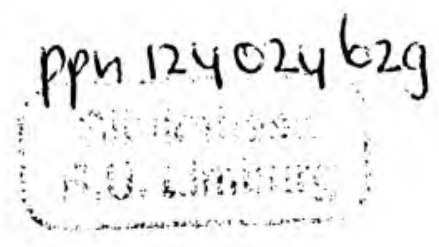

De mens beschikt nog net over voldoende verstand om zich te kunnen realiseren hoezeer het intellect tekort schiet tegenover het bestaande.

Er zou van het menselijk bedrijf in deze wereld een grotere aantrekkingskracht uitgaan als deze bescheidenheid aan allen overgebracht kon worden.

A. Einstein, 1932 
Mijnheer de Rector Magnificus,

Dames en Heren,

Tijdens deze openbare les wil ik $\mathrm{u}$ meenemen in het vakgebied virologie en enkele nieuwe fascinerende aspecten ervan belichten.

Ik hoop u een indruk te geven van datgene war centraal staat in de medische virologie en dat is de RELATIE TUSSEN HET VIRUS EN DE MENS. Her is een flexibele relatie die varieert per virus en per mens. Daarnaast is het ook een relatie die onderhevig is aan zowel interne (binnen de mens zelf) als van externe (buiten de mens) factoren. De invloed van deze factoren laat zich het best illustreren aan de hand van het verschijnsel nieuwe virusziekten. De relatie virus-mens is niet alleen variabel en beïnvloedbaar maar is ook van grote betekenis voor de volksgezondheid. Willen wij echrer ingrijpen in deze relatie, dan is kennis nodig van zowel het virus als van de mens, en in het bijzonder van de afweer van de mens tegen virusinfecties. Dat deze relatie ook spannend is, zal moeten blijken uit de inhoud van deze rede.

\section{Inleiding}

In de pers, maar ook in de vakliteratuur, verschijnen er regelmatig berichten over 'nieuwe virusziekten'.

Een treffend voorbeeld hiervan is uiteraard AIDS dat met een zekere regelmaat aanleiding geeft tot ophefmakende artikels. Ook andere, zij het ietwat minder bekende virusziekten, trekken de aandacht. Zo bijvoorbeeld kreeg de zeehondenziekte wereldwijd belangstelling toen er aan het eind van de jaren tachtig bij de zeehonden in NoordwestEuropa een plotseling sterfte werd vastgesteld. Ook de 'gekke koeienziekte' in Engeland haalde de pers rond 1990 en het zijn nu de infecties, veroorzaakt door een hantavirus, die in de U.S.A. erg in de 
belangstelling staan wegens het plotseling optreden van enkele dodelijke slachtoffers.

De vraag is nu: betreft dit infecties met echt 'nieuwe' virussen of zijn het 'oude' virussen waarvan we her bestaan tot nog toe niet kenden of betreft dit ziekten veroorzaakt door reeds lang bekende virussen, maar waarvan we niet wisten dat ze een dergelijk ziekrebeeld konden verooraken?

Ik zal trachten op al deze aspecten in te gaan en zal dit grotendeels doen aan de hand van (historische) voorbeelden. Met opzet zal nauwelijks worden ingegaan op HIV, het virus dat AIDS veroorzaakt, en wel om de volgende redenen:

- ten eerste krijgt dit virus mijns inziens al aandacht genoeg;

- ten tweede zijn er een hele rij andere virussen die, alhoewel ze vaak wat minder bekend zijn, toch een zeer interessant gedrag vertonen en soms zelfs op het AIDS-virus lijken (sommige hiervan zal ik in het kort bespreken);

- ten derde heeft AIDS, zeker voor wat betreft het fundamenteel onderzoek, niet de hoogste prioriteit in onze instelling; hier in Maastricht willen wij ons in de komende jaren bezighouden met een herpesvirus dat bij de mens chronische infecties veroorzaakt en waarvan we nog bitter weinig weten.

Ik hoop dat het $u$ aan het eind van mijn verhaal dan ook duidelijk mag zijn wat een boeiend vakgebied de virologie in feite is en wat het belang is van het virologisch onderzoek voor de volksgezondheid.

Ook zal ik trachten aan te geven met welke aspecten van het vakgebied wij ons in Maastricht bezig houden.

Vooraleer op het onderwerp 'nieuwe virusziekten' in te gaan zal ik eerst wat vertellen over: 
- wat virussen zijn

- hoe ze zich vermeerderen

- hoe ze de gastheer ziek kunnen maken

Daarna zal ik ingaan op de 'nieuwe' ziekten, die soms veroorzakt worden door zgn. 'nieuwe' virussen, maar vaak ook door zgn. 'oude' virussen.

\section{Wat zijn virussen?}

Als we de geschiedenis van de virologie erop naslaan dan blijkt dat we nog niet zo heel lang weten wat virussen precies zijn. Wel is bekend, zeker sinds het begin van deze eeuw, dat bepaalde ziekten veroorzaakt worden door microörganismen, ook microben genoemd. Het was Antonie van Leeuwenhoek die aan het eind van de $17 \mathrm{e}$ eeuw het bestaan beschreef van kleine, bewegende 'dierrjes' (microörganismen), die hij kon waarnemen (mer behulp van zijn zelfgebouwde microscoop) in regenwater en in tandbeslag. Men wist toen echter nog niet dat deze microörganismen een rol speelden in het ontstaan van bepaalde ziekten (infectieziekten). Het is pas aan het eind van de $19 \mathrm{e}$ eeuw - begin $20 \mathrm{e}$ eeuw dan men weet dat sommige microörganismen bepaalde ziekten zoals lepra, miltvuur en cholera veroorzaken kunnen.

In de geschiedenis blijkt dat infecties vaak een belangrijke en soms dé belangrijkste oorzaak van ziekte en dood zijn geweest. Het klassieke voorbeeld is uiteraard de pest. Maar ook andere infecties hebben ernstige epidemieën veroorzaakt. Zo was syphilis in Europa aan het eind van de 15 e eeuw/begin 16 e eeuw (de rijd van Columbus en Erasmus) een ernstig verlopende infectie die we nu 't beste zouden kunnen vergelijken met de AIDS epidemie. De ziekte was zó ernstig 
dat zelfs de leprozen (lepralijders) niet met deze mensen in één gebouw wilden verblijven.

Dat men toen nog het verschil tussen een bacterie en een virus niet kende blijkt uit de naam die men aan deze infectie gaf, nl. de Spaanse pokken of de Franse ziekte (de Fransen noemden haar trouwens Mal de Naples en de Italianen Mal Francesca!). Tot aan het eind van de $19 \mathrm{e}$ eeuw werd het woord virus, wat 'gif betekent, trouwens gebruikt voor elk infectieus agens.

De eerste waarnemingen dat er naast bacteriën, die men door filtreren kon verwijderen, ook nog andere, met name kleinere microörganismen voorkwamen, die wel door een filter heen konden, dateren uit het eind van de vorige eeuw. Deze kleine microörganismen noemde men derhalve 'filtreerbare virussen'. Het was Martinus W. Beijerinck die rond 1890 antoonde dat de verwekker van een ziekte bij de tabaksplant een filter kon passeren (het tabaksmozaiekvirus). Naast de plantenvirussen werden er ook dierlijke virussen gevonden, beginnend bij het mond- en klauwzeervirus, gevolgd door pokken- en poliovirus en vervolgens vele andere.

De virologie als aparte wetenschap begint eigenlijk pas in de jaren vijftig (na de ontdekking van de structuur van het DNA door Watson \& Crick). Het eerste virologie handboek 'General Virology' werd in 1953 door S.E. Luria gepubliceerd. Het eerste tijdschrift waarin uitsluitend artikels over virussen opgenomen werden, starte iets eerder, nl. in 1939, met als titel 'Archiv für die gesamte Virusforschung', her huidige 'Archives of Virology'. Vanaf medio deze eeuw volgden er vele andere tijdschriften, o.a. 'Virology' en 'Progress in Medical Virology'. Ook in die tijd ontstonden de eerste virologie instituten, m.n. in Berkeley in 1952 en in Tübingen in 1954.

Als we er nu een virologie boek op naslaan, dan vinden we bij de definitie 'virussen' ongetwijfeld dat ze behoren tot de kleinste levende 
organismen die niet zichtbaar zijn met behulp van een lichtmicroscoop; dat ze ofwel DNA of RNA als drager van het erfelijk materiaal bezitten, hetgeen uniek is in de natuur en bovenal dat ze levende cellen nodig hebben om zich te vermeerderen. Ze worden ook nog beschouwd als de overgang tussen 'levend' en 'levenloos' (aan de eigenschap dat ze als kristallijne vormen kunnen voorkomen, ontlenen ze het attribuut 'levenloos'; het feit dat ze zich kunnen vermenigvuldigen, geeft ze de eigenschap 'levend').

Dus niet alleen hun grootte is kenmerkend, maar vooral de wijze waarop ze zich vermenigvuldigen. Her zijn obligaat intracellulaire parasieten, wat wil zeggen dat ze levende cellen nodig hebben om te groeien. Deze cellen kunnen cellen zijn van insekten, zoogdieren, vissen, planten en ook bacteriën kunnen virussen bevatren. Kortom, ze zijn alom vertegenwoordigd!

De kleinste virussen hebben een eenvoudige structuur bestaande uit het genetisch materiaal (het nucleinezuur) dat omgeven is door een eiwitmantel (capside). De meer complexe virussen zijn niet alleen groter maar hebben nog een extra jas: de envelop om de capside heen; daarnaast hebben ze ook, zoals bijv. het pokkenvirus, enzymen die nodig zijn voor de replicatie bij zich. Dit is in tegenstelling tot de kleinere virussen die voor hun replicatie gebruik maken van de cellulaire enzymen.

Naast deze 'klassieke' virussen zijn er nog de viroïden, virino's en prions. Viroïden zijn kleine cirkelvormige RNA-molekulen die bij planten voorkomen. Virino's zouden bestaan uit nucleïnezuur en geassocieerd zijn met eiwit van de gastheer (dus géén eigen viruseiwit bevatten). De samenstelling van prions is helemaal onduidelijk: ze zouden zelfs géén nucleinezuur bezitten en géén immuniteit opwekken. Het feit dat ze geen eigen nucleïnezuur hebben, leidt automatisch tot de vraag in hoeverre we hier echt te maken hebben 
met een levend organisme. Ze worden in verband gebracht met de langzame virusinfecties (de zgn. 'slow viruses') als Creutzfeldt-Jacob ziekte, Kuru en Scrapie. Deze laatste zou verband houden met de gekke koeienziekre waar ik later in mijn verhaal nog op terug zal komen.

\section{Hoe vermeerderen virussen zich?}

De vermeerdering van een virus gebeurt in de cel en is te onderscheiden in een aancal opeenvolgende stappen.

Ten eerste moet het virus een cel binnenkomen; hiervoor is nodig dat er aanhechting plaatsvindt tussen de buitenkant van het virus en de buitenkant van de cel. Dit gebeurt middels 'specifieke' receptoren; dit zijn structuren (glycoproteïnen) op het oppervlak van de cel die een hechte binding toelaten met bepaalde structuren op het virus oppervlak. Het meest bekende voorbeeld hiervan is bij HIV de binding tussen het glycoproteïn gpl20 van het virus en de $\mathrm{CD}_{4}$ recepror op de cel.

Andere virussen maken gebruik van andere celreceptoren, bijv. rhinovirus, het virus dat verkoudheid geeft, gebruikt ICAM-1 als receptor, een molecuul dat van belang is voor de interactie tussen onze lichaamscellen.

Van vele virussen echter is de receptor nog niet bekend en weten we derhalve niet precies hoe een virus zich aan een cel bindt. Het is wel duidelijk dat de interactie virus - cel via de receptor specifiek is en dat deze van invloed is op het soort cellen dat geïnfecteerd wordt, hetgeen uiteraard ook van belang is voor de ziekte die optreden kan na een infectie.

$\mathrm{Na}$ de aanhechting komt het virus in de cel binnen via diverse mechanismen, zoals fagocytose. Ook dit proces is nog grotendeels 
onduidelijk. Wel is zeker dat bij virussen met een envelop deze aan de buitenkant van de cel blijft; er treedt een 'versmelting' op van de envelop van het virus met de celmembraan( het virus laat als het ware zijn buitenste jas achter) en zo komt het 'naakte' virus (dit is nucleïnezuur en capside) de cel binnen. $\mathrm{Na}$ de binnenkomst begint de eigenlijke vermeerdering, en wel zó dat eiwit èn nucleïnezuur afzonderlijk worden geproduceerd. In plaats van voor zichzelf te zorgen gaat de cel dan onderdelen van het virus maken en gebruikt hiervoor cellulaire enzymen (grotere virussen hebben enzymen bij zich). Meestal gaat de cel uiteindelijk ten gronde aan de virusproduktie. Celdood kan snel optreden, hetgeen het geval is bij virussen, zoals de poliovirussen, die darminfecties geven, maar kan ook langzaam verlopen. Denken we maar aan virussen met een envelop die in de regel langer cel-geassocieerd blijven, zoals het cytomegalovirus.

De cel is dus het 'virusfabriekje' en het virus is de 'dirigent'.

Zo zien we dat niet alleen de aanwezigheid van een receptor op de cel is van belang voor de infectie van een cel, maar ook de aanwezigheid van enzymen in een cel kan bepalen of er virusreplicatie optreedt of niet.

Het kan echter ook zo zijn dat het virus wel in de cel binnenkomt, maar er niet in vermeerdert; dan noemen we dit een abortieve infectie. Dit in tegenstelling tot de produktieve infectie, waar wel virusreplicatie plaatsvindt.

Maar ook andere factoren bepalen of er wel of niet virusreplicatie optreden zal. Zo is een snel-delende cel in regel veel beter geschikr om virusreplicatie toe te laten dan een traag- of niet-delende cel. Het klassieke voorbeeld hiervan is de rodehond virusinfectie tijdens de eerste drie maanden van de zwangerschap. Dit virus geeft vooral schade aan organen die in aanleg zijn (bevatten sneldelende cellen). Een ander voorbeeld uit eigen onderzoek is de interactie van het 
cytomegalovirus met vaatwandcellen. Uit onderzoek in ratren is aangetoond dat dit virus, dat aanwezig is in de vaatwand, pas dan een actieve replicatie geeft als de gladde spiercellen in her vat gaan delen ten gevolge van een lokale beschadiging.

Nog andere factoren zoals de temperatuur blijken van belang te zijn voor het optreden van een infectie. Zo blijken rhinovirussen, die de veroorzakers zijn van verkoudheid, zich beter te kunnen repliceren bij iets lagere remperatuur (optimum lige bij $33^{\circ} \mathrm{C}$ ), waardoor ze aangepast zijn voor de lagere temperatuur in de neusholte.

\section{Hoe maken virussen ons ziek?}

Als we dit proces (virus-cel) nu op het niveau van de hele mens bekijken dan blijkt dat het lichaam diverse verdedigingsmechanismen bezit om bescherming te bieden regen deze vreemde indringers die de cellen kunnen kapotmaken. Globaal is deze verdediging opgebouwd uit enerzijds de niet-specifieke afweer en anderzijds uit de specifieke afweer.

Tor de niet-specifieke afweer, die fungeert als eerste barrière, behoren o.a. de intacte huid die geen virus doorlaat (met uitzondering van het wrattenvirus), de maag waar de zure $\mathrm{pH}$ vele virussen vernietigt, de darm waar de galzure zouten virussen met een envelop denatureren. Kortom, een virus moet vele barrières passeren vooraleer het een cel kan bereiken om deze vervolgens te infecteren.

Ook een stof als interferon speelt een rol in de niet-specifieke afweer; deze stof wordt gevormd bij een virusinfectie en zorgt ervoor dat de omliggende cellen beschermd worden tegen nieuwe virusinfecties.

De specifieke afweer, ook wel immuniteit genoemd, beschermt het lichaam tegen een welbepaald ('specifiek') microorganisme. Deze immuniteit is complex en is op te splitsen in 2 delen: de humorale 
(oplosbare) immuniteit (antistoffen) en de cellulaire immuniteit (cellen). Beide zijn specifiek gericht tegen een virus of zijn componenten (antigenen).

De vaccinatie die voor de preventie van virale infecties van wezenlijk belang gebleken is, is gebaseerd op de humorale immuniteit en houdt in dat na de blootstelling van het lichaam aan een vreemd parrikel (een antigeen), bijv. een gedood viruspartikel of een deel ervan, er antistoffen gemaakt worden. Deze beschermen de gastheer tegen (re)infekties met hetzelfde of een nauw verwant virus. Dat vaccinaties bij bepaalde virussen goed werken, blijkt uit het feit dat met behulp van een wereldwijd vaccinatieprogramma de pokken werden uitgeroeid (het laatste geval van pokken was in 1977 in Ethiopië). Ook de vaccinatie tegen polio, bof, rode hond en mazelen, die in West-Europa algemeen worden toegepast bij jonge kinderen, blijken effectief te zijn in de preventie van de betreffende ziekten.

Dat dit echter niet bij alle infecties zo effectief is, blijkt uit de resultaten van de vaccinatie tegen het influenzavirus. Dir virus is blijkbaar in staat is om zichzelf zodanig te veranderen dat de vaccinatie niet afdoende beschermt tegen infectie met het influenzavirus dan de volgende winter(s) optreedt. Het gevolg is dat we ons zowat jaarlijks moeten laten vaccineren tegen griep voor optimale bescherming.

De cellulaire immuniteit is vooral van belang bij deze infecties waar het virus langere tijd celgeassocieerd blijfr; dit is o.a. het geval bij herpesvirussen. Vermindering van de cellulaire immuniteit, hetzij door therapie, bijv. na een orgaantransplantatie, hetzij door ziekte, leidt dan tot ernstig verlopende infecties. Het meest karakteristieke voorbeeld hiervan is het cytomegalovirus. Dit virus dat tor de herpesvirusgroep behoort, geeft bij normaal gezonde personen nauwelijks ziekte. Echter, toen in 1967 door Chr. Barnard in het 
Grote Schuurziekenhuis in Kaapstad de eerste harttransplantatie plaatsvond, was dit meteen ook de start van het 'cytomegalovirustijdperk'. Het virus gaf bij zowat alle ontvangers van een transplantatie-orgaan actieve infecties met soms ernstige komplikaties.

De algemene regel is dat immuniteit goed is voor de bescherming tegen infectieziekren en dus voor de overleving van de gastheer.

De keerzijde van de medaille echter is dat deze goedbedoelde vorm van verdediging ook wel eens 'ontspoort' en niet alléén gericht is tegen de vreemde indringers, maar ook tegen lichaamseigen componenten/cellen: we spreken dan van autoimmuniteit. Dit treedt bij vele virusinfecties op. Zo zou dit bij een Coxsackie-B-virusinfectie, die normaliter vrij onschuldig verloopt, kunnen leiden tot ontsteking van de hartspier (myocarditis).

Er bestaat als het ware een evenwicht tussen de microorganismen die ons bedreigen en onze afweer die deze infecties tegenhoudr, of binnen de perken houdt.

Slaagt een microörganisme er toch in om de barrière(s) te doorbreken en krijgt her de kans om onze cellen te infecreren, dan reageert het lichaam hierop met de vorming van antistoffen en het ontwikkelen van cellulaire immuniteit die, als alles goed verloopt, in staat is om deze infectie een halt toe re roepen. We worden misschien wel ziek, maar worden daarna weer beter. Dat evenwicht vinden wij, tenminste als alles in orde is, zeker in de westerse wereld meestal wel weer snel terug. We bereiken allemaal meestal een hoge leefrijd hetgeen erop duidt dat we de vele infecties hebben weten te voorkómen of te overwinnen. Aan dat laatste hebben factoren als toegenomen hygiëne, goede voeding en voorlichting zeker een grote en misschien wel de grootste bijdrage geleverd. Ook voorkómen van vele infecties door vaccinatie is uiteraard van invloed geweest op de overleving. Dat vele (soms minder bekende) factoren onze afweer beïnvloeden 
blijkt bijv. uit het ernstig verloop van mazelen bij kinderen in de derde wereld. Waar mazelen in de westerse wereld een zowat onschuldige kinderziekte is, blijkt bij slechte voeding of ondervoeding deze infectie zeer ernstig te verlopen met vaak fatale afloop. Ook psychische factoren waaronder stress en depressie zijn van invloed op onze afweer. Het best bekende voorbeeld is de koortslip veroorzaakt door een herpes simplex virusinfectie of gordelroos door het waterpokkenvirus, die onder invloed van stress optreden kunnen.

Sommige virussen echter zijn in staat om te ontsnappen aan het afweersysteem van de gastheer en kunnen hierdoor in de gastheer overleven zonder deze ziek te maken. We noemen dit verschijnsel: latentie. Vanuit deze als het ware slapende toestand die latentie in feite is, kan het virus reactiveren. Reactivatie leidt tot produktieve infectie wat inhoudt dat er vrij virus gevormd wordt dat dan ten eerste bij de gastheer ziekte kan geven en ten tweede zich kan verspreiden naar andere (nieuwe) gastheren. Een gezamenlijk voortbestaan, een soort 'vreedzame coëxistentie' van gast en gastheer is een vorm die voor beide, maar zeker voor het virus een goede zaak is.

We moeten ons m.n. realiseren dat het virus er meestal geen enkel voordeel bij heeft om zijn gastheer uit te schakelen. Immers: zonder gastheer: geen virus! Als de gastheer te snel dood gaat, heeft het virus geen kans om een volgende gastheer te vinden (hetgeen het nodig heeft voor zijn overleving). We zien dan ook dat vele 'nieuwe' infecties die in het begin ernstig verlopen, na verloop van tijd een milder verloop hebben. 'Nieuwe' virussen die aanvankelijk vele van hun gastheren doden, lijken op termijn te 'veranderen' naar een vorm die zowel voor het virus als voor de gastheer optimaal zijn. Natuurlijke selectie leidt uiteindelijk tot verminderde virulentie van het virus en gastheerresistentie. Her beste voorbeeld hiervan is het 'myxomatose- 
virus'. In de $19 \mathrm{e}$ eeuw werden konijnen in Australië geïmporteerd; deze hadden geen natuurlijke vijand waardoor ze ongeremd in aantal konden toenemen. Rond 1950 werd het myxomatose-virus geïntroduceerd in Australië; dit virus veroorzaakte in het begin een sterfte bij 80-90\% van de dieren. Later werd dit minder en werd dit sterftecijfer teruggebracht tot nagenoeg $20 \%$. Men heeft uitgerekend dat het ongeveer 6 generaties (van de gastheer) duurt om deze afgezwakte virusvorm te bereiken (bij de mens zou dit als we deze 6 generaties hanteren als tijdspad nagenoeg 125 jaar zijn).

Over het verschijnsel latentie en reactivatie wil ik nog nader ingaan omdat dit mijns inziens een vrij belangrijk fenomeen is dat voor de gastheer en in het bijzonder de mens nog vele onbekende facerten heeft.

Met de toename in kennis van virussen en van de afweer van de gastheer blijkt dat waar men aanvankelijk dacht dat dé, om niet te zeggen alle, virussen na infectie (en genezing) de gastheer verlaten blijkt dit echter in vele gevallen niet zo te zijn. Nogal wat virussen blijken na de infectie in de gastheer te blijven zitten zonder deze ziek te maken: het zijn latente virussen geworden.

We kennen allemaal het voorbeeld van waterpokken. Deze bekende ziekte treedt meestal op kinderleeftijd op en wordt veroorzaakt door infectie met een herpesvirus, het waterpokkenvirus. $\mathrm{Na}$ deze infectie, waarvan men meestal goed geneest zonder restverschijnselen, blijft het virus in het lichaam zitten, m.n. in cellen van het centrale zenuwstelsel. Onder bepaalde omstandigheden, waaronder stress of bij verlaagde cellulaire immuniteit, komt het virus uit deze cellen vrij (reaktiveert) en geeft een actieve infectie die leidt tot het beeld wat we kennen als gordelroos.

Naast waterpokkenvirus zijn er nog vele andere meer of minder bekende virusinfecties die leiden tor latentie. In de regel is dit het 
geval bij alle herpesvirussen. De koortslip die optreedt bij reactivatie van herpes simplex virus is een goede bekende bij velen van ons. Factoren zoals stress, verlaagde afweer, koorts en hormonale veranderingen blijken een rol te spelen in dit reactivatieproces.

\section{'Nieuwe virusziekten'}

Hoe zit dat nu met de zgn. nieuwe virusziekten?

Worden deze veroorzaakt door nieuwe virussen, of worden die veroorzaakt door tor nog toe onbekende virussen, of betreft het veranderingen (mutaties) van bestaande virussen, of zijn het ziektebeelden veroorzaakt door bekende virussen, maar waarvan wij, door hiaten in onze virologische kennis, nog niet van op de hoogte waren dat ze een virale oorsprong hebben.

Op al deze vragen zal ik proberen in te gaan met behulp van een aantal voorbeelden uir de praktijk.

\section{Veranderingen in het ecosysteem}

Veranderingen in het ecosysteem kunnen leiden tot 'nieuwe' virusziekten, hetgeen het best is aangetoond bij infecties veroorzaakt door arbovirussen. Arbovirussen vormen een grote uiteenlopende virusgroep, waarvan er nu meer dan 500 virussen bekend zijn, die als gemeenschappelijk kenmerk hebben dat ze overgebracht wordt via geleedpotigen (arthropoden), o.a. teken en muggen. Door veranderingen in de natuurlijke omgeving van deze geleedpotigen, zoals bij ontbossing, irrigatie, introductie van nieuwe diersoorten en ongekontroleerde urbanisatie treden er wijzigingen op in de leefwereld van deze arthropoden. Dan ontstaan er automatisch veranderingen bij de verspreiding van de virussen die zij met zich meedragen. 
Ook lange afstandsverkeer, o.a. reizen, blijkt van invloed te zijn op het voorkomen van deze arbovirusinfecties. Zo is in het kader van de verspreiding van deze infecties enkele jaren geleden een onderzoek verricht naar de aanwezigheid van arthropoden in vliegtuigen die interkontinentale vluchten makten. Bij dit onderzoek bleek dat er in vliegruigen die zich op de luchthaven bevonden van Nairobi, Kenya, er 13 verschillende soorten muggen en muskieten gevonden werden. Als we weten dat deze muggen virussen bij zich kunnen hebben en ze ook kunnen overbrengen op mens en dier dan beseffen we meteen ook dat verplaatsing van deze muggen via transportroutes ook introductie van nieuwe soorten virussen met zich mee kan brengen op andere lokaties.

Dengue is een van de zich snelst uitbreidende ziekten in de tropen met miljoenen gevallen elk jaar. De toename wordt geweten aan de voortschrijdende urbanisatie waardoor de concentratie aan muggen groter is geworden. Er zijn twee ziektebeelden bekend: de Dengue koorts, en de ernstige vorm: de Dengue hemorrhagische koorts. Deze ziekte kwam vroeger uitsluitend voor in Azië, maar is sinds enkele jaren in Amerika en dan voornamelijk in het Caribisch gebied vastgesteld (in Puerto Rico zijn 6 epidemieën in de laatste 12 jaar gekonstateerd).

Gele koorts heeft al een lang historisch verleden. De infecrie werd in de $17 \mathrm{e}$ eeuw overgebracht met de slaven vanuit Afrika naar Amerika (o.a. Cuba). Daar waar de boot met besmette slaven aankwam, leidde dit tot massale infecties van de plaatselijke bevolking.

De vector van beide virussen is de mug Aedes aegypti (= de Afrikaanse regenwoudmug). Deze mug leeft in de onmiddellijke nabijheid van de mens (is goed aangepast) en neemt sterk in aantal toe (de bestrijdingsprogramma's zijn grotendeels mislukt). 
Maar ook een andere mug kan deze virussen overbrengen (want niet elke mug kan elk arbovirus overbrengen!) m.n. de Aedes albopictus (= de Aziatische rijgermug). Deze mug is 10 jaar geleden in Amerika binnengebracht vanuit Japan. Dit gebeurde met schepen die gebruikte autobanden vervoerden. In deze autobanden was vocht (resten regenwater) aanwezig waarin zich de betreffende muggelarven bevonden. Deze mug heeft zich goed kunnen handhaven in haar nieuwe thuisland (Amerika) en kan beide virussen overbrengen en doet dit zelfs efficiënter dan de mug Aedes Aegypti. Daarbij komt nog dat de Aziatische tijgermug beter aangepast is aan het klimaat in Noord-Amerika en 's winters overleven kan.

Beide muggen vullen elkaar als het ware aan, $\mathrm{nl}$. de ene (Aedes aegypti) leeft bij voorkeur in huis en de andere, Aedes albopictus, leeft rondom het huis (in struikgewas).

Beide virussen geven in deze muggen hoge viremieën, d.w.z. hoge viruskoncentraties in het bloed, waardoor ze bij een muggebeet dan ook goed overgebracht worden naar de gastheer, zelfs mer zéér kleine hoeveelheden bloed.

\section{Veranderende (muterende) virussen}

'Veranderende' virussen, je zou ze ook 'zichzelf vernieuwende' virussen kunnen noemen, bestaan ook. Het best bekend is het influenzavirus. Infecties met het influenzavirus zijn een voorbeeld van virale evolutie. Nagenoeg elke 30-40 jaar ontstaat er een 'nieuw' virus en dit 'nieuwe' virus geeft wereldwijde epidemieën (pandemieën). Tussendoor zijn er kleinere veranderingen aan het virus te konstateren die ook epidemieën veroorzaken kunnen. Het virus evolueert en deze evolutie wordt bepaald door de gastheer. Als vele mensen immuun zijn tegen een bepaald influenzavirus, dan kan er geen (massale) infectie meer optreden en evolueert het virus naar een 
dusdanige vorm (nieuw virus) waartegen geen immuniteit is zodat de infecries weer (massaal) mogelijk zijn. De immuniteit van de gastheer beïnloedt de evolutie dus. Waarom dit nu precies bij dit virus gebeurt en niet bij andere virussen ligt aan een complex van factoren. De belangrijkste factoren zijn:

a) 'de aard van het beestje (het virus) zelf. Het virus heeft aan de buitenkant rwee soorten uitsteeksels: het hemagglutinine en het neuraminidase waartegen het lichaam antistoffen maakt; deze zijn van belang voor de immuniteit en spelen derhalve een rol in het al of niet optreden van herinfecties. Daarnaast bezit het influenzavirus een gesegmenteerd genoom dat gemakkelijk herschikking (reshuffling) toelaat als 2 verschillende virusstammen éénzelfde cel infecteren.

b) het virus beperkt zich niet tot de mens, maar bij vele diersoorten, waaronder vooral watervogels (eenden), komen infecties voor. Deze diersoorten, waarbij we vooral denken aan eenden, paarden en varkens kunnen het virus overbrengen op de mens.

Eigenaardig genoeg is het feit dat 'nieuwe' influenzavirussen in de regel ontstaan in Zuid-China. De verklaring hiervoor zou zijn dat daar een geïntegreerde fok van varkens en eenden bestaat (er zouden trouwens in China meer eenden voorkomen dan mensen!), waardoor uitwisseling van genetisch materiaal van virussen bij beide diersoorten oprreden kan, die dan vervolgens weer bij de mens infecties kan geven. Het feit dat eenden een seizoensgebonden trek hebben, houdt ook in dat de virussen die ze bij zich hebben en die ze in tegenstelling tor de mens ook in de faeces uitscheiden, kunnen verspreiden over grote afstanden. Dus een 'nieuw' virus zou kunnen ontstaan vanuit twee 'voorouder' virussen door 'reshuffling' van de genen van beide 'voorouder' virussen. Door ontbreken van antistoffen tegen dit 'nieuwe' virus 
verloopt de infectie massaal (pandemieën) en ernstig (vele ziekten).

Een bekende pandemie was de uitbraak van de Spaanse griep in 1918, die eigenlijk een verkeerde naam is want ook het influenzavirus van deze uitbraak had zijn wortels in Azië, waarbij wereldwijd 20 miljoen slachtoffers vielen.

De volgende pandemie vond plaats in 1957-1958, nl. de Aziatische griep en wellicht is de volgende te verwachten aan het eind van deze eeuw.

De kennis van dit virus en zijn gedrag en ook zijn verspreiding is van belang voor de ontwikkeling van nieuwe vaccins die ons elke winter behoeden moeten voor nieuwe infecties.

\section{Introductie van een nieuw virus}

De introductie van een virus in een gemeenschap die eerder nog géén contact heeft gehad met dit virus zou uiteraard beschouwd kunnen worden als een nieuw virus (althans voor de inwoners van die gemeenschap). Een haast 'klassiek' voorbeeld hiervan is de uitbraak van pokken in Amerika in de 16 e eeuw. Het waren de Europese ontdekkingsreizigers, m.n. de Spanjaarden, die het pokkenvirus importeerden bij de toenmalige Indianen aldaar (Azteken). Ten gevolge van deze infectie trad er een massale sterfte op. In het eerste jaar stierf nagenoeg $\mathbf{9 0 \%}$ van de plaarselijke bevolking. De Spanjaarden zelf, die de infectie meegebracht hadden, stierven niet. Ze waren namelijk opgegroeid in Europa waar pokken destijds endemisch voorkwamen en waren er immuun tegen. Het gevolg van dit alles was dat de Indianen de Spanjaarden als goden zagen en ze deze epidemie als de straf Gods beschouwden en de overlevende Indianen zich massaal tor het Katholicisme (de godsdienst van de veroveraars) bekeerden. 


\section{Dr. C.A. BRUGGEMAN}

Gelijkaardige uitbraken zijn beschreven bij diverse Indianenstammen in Zuid-Amerika of bij eilandbewoners (o.a. een mazelenepidemie op de Faroeh eilanden in de $19 \mathrm{e}$ eeuw). Het betreft in al deze gevallen de introductie van een bekend virus in een nier-immune gemeenschap waardoor de infectie in de regel ernstig verloopt en vele slachtoffers geeft.

Duidelijk is dat her niet gaat om een nieuw virus, maar om verplaatsing van een virus naar een nieuw territorium.

\section{4. 'Gevaarlijke' nieuwe virussen?}

Kompleet nieuwe virussen leken de Marburg- en Ebola-virussen. Deze veroorzaakten een uitbraak in resp. 1967 en 1976 en zorgden voor een paniekreactie onder gezondheidszorgwerkers en virologen.

Het Marburg-virus veroorzaakte in Marburg (Duitsland) een epidemie onder laboratoriumpersoneel dat met organen (o.a. nieren voor de aanleg van celkweken) van uit Oost-Afrika geïmporteerde apen werkte. Zeven van de 28 geïnfecteerde medewerkers stierven ten gevolge van de infectie. Deze infectie verspreidde zich verder via urine en keelvocht naar het verplegend personeel. Bij deze 'secundair' gë̈nfecteerden vielen er echter geen doden. Alleen de primair geïnfecteerden overleden ten gevolge van de infectie.

Het Ebolavirus veroorzaakte gelijkaardige epidemieën met nog hogere mortaliteit, resp. $88 \%$ en $53 \%$ in Zaïre en Soedan.

Het zijn beide virussen waarvan men aanneemt dat er een dierlijk reservoir aanwezig is in de natuur (het is echter niet bekend in welk diersoort het virus zich schuilhoudt) en die de mens bereiken via de aap. Dus ook hier géén nieuw virus, maar een voor de mens grotendeels onbekend virus - met onbekend ziekteverloop. contact met besmette dieren ligt aan de basis voor de infectie bij de mens. 


\section{Een nieuwe ziekte in Noord-Amerika?}

In het gezaghebbende tijdschrift The New England Journal of Medicine werd in het aprilnummer van dit jaar het editorial gewijd aan het 'nieuwe hantavirus'. Oorzaak was dat er bij 17 personen in het Zuidwesten van de Verenigde Staten een ernstige ziekte van de luchtwegen was vastgesteld. Bij deze uitbraak overleden 13 patiënten. De oorzaak van de ziekte werd gevonden in het laboratorium: het betrof een infectie met een nieuwe telg van de hantavirusfamilie. De hantavirussen werden eertijds in Zuid-Korea gevonden en danken hun naam aan de rivier de Hantaan waar ze aangeroond werden bij veldmuizen en bij mensen die vooral in de rijstteelt werkten. In de jaren vijftig werden er tijdens de Koreaanse oorlog duizenden Amerikaanse soldaten geïnfecteerd met dit virus. Sindsdien zijn er infecties beschreven zowel in Azië als in Europa (vooral NoordEuropa). De nierproblemen die optreden ten gevolge van deze infecties staan hierbij op de voorgrond. Dat deze virussen luchtwegklachten geven, is voor het eerst beschreven bij de recente uitbraak in de Verenigde Staten. Het daar geïsoleerde virus krijgt de naam 'Muerto Canyon' (refereert aan de plaats in Nieuw-Mexico waar het voor het eerst geïsoleerd werd). Knaagdieren vormen het natuurlijke reservoir van dit virus. Onderzoek in de U.S.A. toonde aan dat \pm $30 \%$ van de muizen in de zuidelijke staten van de U.S.A. met dit virus geïnfecteerd is. De uitscheiding gebeurt via urine en faeces. Wanneer de mens in contact komt met knaagdieren of hun verblijf, dan kan het virus ingeademd worden en aldus infectie geven.

De vraag is nu waarom treedt nu plots deze uitbraak op?

Het antwoord hierop is dat klimatologische omstandigheden, maar ook menselijke factoren een rol spelen. Zo zou de hevige regenval en sneeuw in het betreffende gebied na een periode van extreme droogte ervoor gezorgd hebben dat er vele knaagdieren waren, m.n. door de 


\section{Dr. C.A. BRUGGEMAN}

sterke voedseltoename. Ook zouden de leefomstandigheden van de mensen in dit gebied (slechte hygiëne en slechte behuizing) en frequente blootstelling aan de besmerte uitscheidingsprodukten van de knaagdieren geleid hebben tor besmetting.

Ook in dit geval dus géén nieuw virus, maar een nieuw ziektebeeld veroorzaakt door een virus dat normaal bij dieren voorkomt en dat door 'omstandigheden' infectie geeft bij de mens.

\section{6. 'Onconventionele virussen'}

Naast de conventionele virussen, bestaande uit nucleïnezuur en eiwitten die bij een infecrie immuniteit opwekken, zijn er infecrieuze agentia die deze kenmerken niet of slechts ten dele hebben.

Ze veroorzaken infecties met zéér lange incubatietijd, dit is de tijd tussen infectie met het agens en het optreden van symptomen (ziekte).

Veel is onduidelijk bij deze zgn. 'onconventionele' partikels.

$\mathrm{Bij}$ dieren is het best bestudeerde het Scrapie-agens, dat infectie geeft bij schapen en geiren en vooral voorkomt in IJsland en NoordEngeland. De infectie leidt na een incubatietijd van I à 5 jaar tot een fataal aflopende ziekre met schade van het centrale zenuwstelsel. Dit agens wordt verantwoordelijk geacht voor het optreden van de 'gekke koeienziekte' die enkele jaren geleden in Zuidwest-Engeland optrad. De runderen waren geïnfecteerd met het Scrapie-agens door het eten van voeder dat bestond uit afval van geslachte schapen die met het Scrapie-agens geïnfecteerd waren en dat door onvoldoende decontaminatie (middels organische oplosmiddelen) bij de bereiding overleefde.

Bij de mens is Kuru de meest bekende infectie met een slow-virus. De infectie kwam voor bij de Fore-stam in Nieuw-Guinea. Door een vorm van kannibalisme (een ritueel opeten van de organen van de 
overleden verwanten) werd het agens van de ene besmette persoon naar de andere overgebracht. Deze ziekte met een incubatietijd van meer dan 10 jaar tastre de hersenen aan en leidde tor dementie en de dood. Door het afschaffen van het kannibalisme in de jaren vijftig is deze ziekte ook gestopr.

Van een andere ziekte wordt gespeculeerd dat het een infectie betreft met een slow-virus, m.n. de Creutzfeldt-Jacob ziekte. Deze ziekte treedt meestal op middelbare leeftijd op en resulteert in dementie. Hoe de ziekte overgebracht wordt, is onduidelijk; wel zijn er gevallen bekend van overdracht via cornea transplantatie en toediening van het menselijk groeihormoon. Deze ziekte die optreedt bij 1:1.000.000 inwoners, lijkt bij bepaalde bevolkingsgroepen, o.a. Joden uit Libië, meer voor te komen, zodat gedacht wordt dat genetische factoren een rol spelen bij het optreden van de ziekteverschijnselen.

\section{Nieuwe technologie leidt tot ontdekking van nieuwe virussen}

We weten reeds lang dat leverziekten veroorzaakt kunnen worden door virusinfecties. Ook is bekend dat virussen d.m.v. bloed en bloedprodukten kunnen overgebracht worden. Het voorbeeld hiervan is het hepatitis-B-virus. Dat virus dat vroeger Australia antigeen genoemd werd, was echter niet verantwoordelijk voor alle gevallen van hepatitis die via bloedtransfusie optraden. Immers toen men het bloed van donoren ging onderzoeken op de aanwezigheid van het hepatitis-B-virus en zijn antistoffen en geïnfecteerd bloed uitsloot voor donatie, traden er echter nog hepatitis gevallen op. Dus er moest een ander virus bestaan dat niet hepatitis-B, maar ook niet hepatitis- $A$ was; men noemde het non- $A$, non- $B$ hepatitis. Door gebruik van recombinant DNA technieken werd het virus in de 
U.S.A. geïdentificeerd en hepatitis-C genoemd. Een nieuw virus was geboren!

Dit is een voorbeeld van een op klinische en epidemiologische basis verwacht virus dat nu ook voor de laboratoriumwerker bestaar! Het oorzakelijk agens (virus) van een reeds bekende infectieziekre was geidentificeerd, maar nieuw is het virus uiteraard niet te noemen!

\section{Nieuwe ziektebeelden ontstaan ten gevolge van veranderingen op 'microniveau'.}

Eerst zou de vraag gesteld kunnen worden: 'Is het ziekmakend vermogen van alle virussen bekend'?

Het antwoord hierop is dan: 'Neen, zeker niet'!

Van een aantal virussen is duidelijk wat ze doen of dat denken we tenminste. Zo geeft infectie met een rhinovirus verkoudheid; geeft infectie met heparitis-B-virus hepatitis; geeft infectie met rotavirus diarree. Maar is dit het enige wat deze virussen doen of geven ze in kombinatie met andere (gastheer)factoren ook aanleiding tot andere (onbekende) ziekrebeelden? Duidelijk is dat er van vele infecties geen duidelijk ziektebeeld is, b.v. weten we niet precies wat reovirussen doen; we weten ook niet precies wat de nieuwe herpesvirussen (humaan herpes- 6 en -7) doen en ook voor vele enterovirussen is dit het geval. Geeft het Coxsackie-B-virus wel echt myocarditis? Wat is de rol van papillomavirussen bij het ontstaan van baarmoederhalskanker?

In voorgaande punten zijn een aantal nieuwe virusziekten vernoemd al deze zijn het gevolg van veranderingen in het natuurlijk milieu van de mens. Sociale ontwikkelingen liggen ten grondslag aan het ontstaan en de verspreiding van vele nieuwe virusziekten. 
Maar naast de veranderingen op macroniveau zijn er ook veranderingen op het niveau van de mens zelf (microniveau) die voor een gewijzigd ziekteverloop kunnen zorgen.

Zo kent het ziekteproces van bepaalde virale infecties een ernstiger verloop ten gevolge van 'het medisch handelen'. Denken we maar aan de orgaantransplantaties. Bij de ontvangers van een (donor)orgaan wordt immuunsuppressieve therapie toegepast zodat het getransplanteerde orgaan niet afgestoten wordt. Ten gevolge van de immuunsuppressie echter kunnen wel bepaalde virusinfecties ernstiger verlopen. Het meest bekende voorbeeld hiervan is het cytomegalovirus dat bij de normaal gezonde gastheer een subklinisch verloop (zonder klinische symptomen) kent. Dat deze infectie frequent voorkomt, blijkt uit het aantal mensen dat antistoffen bezit tegen dit virus - in West-Europa is dit bij 30-40\% bij 30-jarigen en nagenoeg $50-60 \%$ bij 50 -jarigen. $\mathrm{Bij}$ de ontvangers van een getransplanteerde nier echter komen infecties niet alleen frequent voor (gemiddeld in ongeveer $75 \%$ van de gevallen), maar kennen deze ook vaak een ernstig verloop. In het begin van de jaren zeventig was dit een belangrijke oorzaak van het falen van de niertransplantaties. Echter door verbetering in de behandeling en in het bijzonder door een meer selectieve immuunsuppressieve therapie zijn er beduidend minder acure infecrieproblemen.

De laatste jaren gaat de aandacht in toenemende mate uit naar de lange termijn complicaties. Zo is de chronische afstoting een ernstig probleem dat gedurende de jaren volgend op de transplantatie optreedt. De chronische afstoting is in feite een vaatwandprobleem en wordt ook wel versnelde arteriosclerose genoemd. Het syndroom wordt gekenmerkt door een vernauwing van de vaten in het getransplanteerde orgaan, hetgeen uiteindelijk resulteert in een dysfunctio- 
neren van het betreffende orgaan, waardoor retransplantatie noodzakelijk is.

Alhoewel er over her mechanisme hiervan nog vele onduidelijkheden bestaan, is bij harttransplantatie patiënten aangetoond dat cytomegalovirusinfecties hierbij een rol spelen. Zo blijkt de chronische afstoting eerder op te treden bij geïnfecteerde patiënten en zijn de klinische symptomen ernstiger dan bij de niet-geïnfecteerden. Onderzoek in proefdieren (ratten) in ons eigen laboratorium heeft dit inmiddels bevestigd.

Dat infecties al dan niet vergezeld van klinische symptomen optreden ten gevolge van exogene infecties (dat wil zeggen virus dat van buitenaf het lichaam binnenkomt), is algemeen bekend. Maar ook endogene infecties die ontstaan ten gevolge van de reactivatie van latente virussen kunnen klinische symptomen geven. Het optreden van deze endogene (re)infecties ontstaat vooral bij verminderde, voornamelijk cellulaire, immuniteit. Meest bekend voorbeelden zijn herpesvirus reactivaties, zoals de koortslip bij het herpes simplex virus type-1 en de gordelroos ten gevolge van reactivatie van het waterpokkenvirus. Ook bij het cyromegalovirus is een dergelijke reactivatie mogelijk, alhoewel minder bekend door her (vooralsnog) ontbreken van een duidelijk ziektebeeld.

Onderzoek in eigen laboratorium heeft inmiddels aangetoond dat het virus latent aanwezig is in de gladde spiercellen van de varen van het merendeel van de geïnfecteerde personen. Dat het virus latent aanwezig is in de vaatwand zou tot gevolg kunnen hebben dat reactivatie een lokaal ontstekingsproces induceert die vervolgens lokale schade in het vat teweeg brengt en door het chronisch karakter ervan een bijdrage levert aan het ontstaan van atherosclerose. Niet alleen de aanwezigheid van het virus in het vat, maar ook in bloedcellen, zou van betekenis kunnen zijn voor het ziekteverloop. Immers 
aanwezigheid van latent of reactiverend virus in monocyten en macrofagen leidt tot functionele veranderingen die vervolgens ook voor de vaatwandcellen en in het bijzonder de endotheelcellen van belang zou kunnen zijn.

Dat herpesvirussen een rol kunnen spelen bij het ontstaan van atherosclerose is inmiddels door diverse onderzoekers aangegeven. Zo is uit het onderzoek van Fabricant met het Marek virus aangetoond dat infectie bij kippen leidt tot atherosclerose. Ook bij andere herpesvirussen en in het bijzonder bij het cytomegalovirus zijn er aanwijzingen dat er vaatwandschade optreedt waarbij de rol van het endotheel, maar ook van de witte bloedcellen een voorname plaats inneemt.

Daar het proces chronisch en multifactorieel lijkt te zijn, maakt het uitzoeken van het mechanisme bijzonder moeizaam. Zeker lijkt te zijn dat ook gastheerfactoren een belangrijke rol spelen in dit proces.

\section{Nieuwe virussen en/of nieuwe virusziekten?}

Samengevat zou men kunnen stellen, dat er inderdaad nog nieuwe virussen gevonden worden. Voorbeelden hiervan zijn de recence ontdekkingen van hepatiris- $C$ en humaan herpes-6-virus. Maar, zeker ten aanzien van chronische ziektebeelden, zijn er nog nieuwe gegevens te verwachten over de rol van virale pathogenen bij het ontstaan ervan. De meerderheid van de nieuwe virusziekten, echter, wordt veroorzaakt door zgn. 'oude' virussen die een nieuwe gastheer, in casu de mens, vinden. Dit gebeurt meestal via contact met dieren (muggen, apen, knaagdieren) of dierlijke produkten. Ook veranderingen (mutaties) ter hoogte van het virus zelf kunnen leiden tot nieuwe virusziekten.

In het algemeen, echter, ligt het menselijk handelen ten grondslag aan het optreden van deze nieuwe virusziekten. 


\section{Dr. C.A. BRUGGEMAN}

Dit betreft veranderingen op macroniveau waardoor de leefomstandigheden van mensen, maar ook van dieren wijzigen. Voorbeelden hiervan zijn landbouw en transport, die beide ten grondslag liggen aan een aantal nieuwe virusziekren. Maar ook veranderingen aan de gastheer zelf, op microniveau dus, kunnen nieuwe virusziekten introduceren. Bekend zijn de virusziekten na orgaantransplantaties en na therapie met immuunsuppressiva.

\section{Beschouwingen en toekomstperspectieven}

Door het gebruik van antibiotica voor bacteriële infecties en effectieve vaccinaties voor virale infecties had de westerse wereld in de jaren zestig nog nauwelijks belangstelling voor infectieziekten. Het was zo ver gekomen dat de dekaan van de Medical School van de John Hopkins University in de U.S.A. verklaarde dac er nu meer aandacht besteed zou moeten worden aan chronische ziekten, in plaats van aan infectieziekten. Nu 20 jaar later heeft hij inmiddels deze stelling ingetrokken. Door veranderingen die vooral ontstaan ten gevolge van menselijk ingrijpen in de natuurlijke omstandigheden kunnen ze toeslaan, maar ook door vooruitgang in het medisch handelen (o.a. orgaantransplantaries) kunnen relatief onschuldige virussen ernstig verlopende ziekten veroorzaken.

De relatie tussen virus en gastheer is een wankel evenwicht die beïnvloed wordt door vele factoren, zowel aan de kant van het virus als aan de kant van de gastheer. Al met al is het een boeiende en ook spannende relacie!

$U$ zult begrijpen dat, willen wij meer inzicht krijgen in de rol van virale infecties bij het ontstaan van diverse ziektebeelden en in het bijzonder van de chronische ziekreprocessen, wij ook meer kennis moeten hebben over de virussen (en virö̈den, prions ...) zelf. Immers 
als van deze microörganismen hun opbouw en replicatie beter bekend zijn, kunnen wij wellicht hun bijdrage aan het ziekteproces verklaren en, waar nodig, op termijn wellicht ingrijpen via vaccinatie en/of antivirale therapie. Hiervoor is fundamenteel onderzoek noodzakelijk. Door gebruik te maken van biochemische en moleculair biologische technieken kunnen wij onze virologische kennis uitbouwen. Maar ook de kennis van de levende cel, de orgaansystemen en de afweer van de gastheer zijn hierbij van groot belang.

Samengevat kan gesteld worden dat basaal virologisch onderzoek ingebed dient te zijn in verwant biomedisch onderzoek zoals celbiologie, immunologie, pathologie en biochemie. Deze multidisciplinaire aanpak van het onderzoek is één van de grondpeilers van het Maastrichtse onderzoek en vormt in dit opzicht een goede basis.

De thematiek van Hart- en Vaatziekten, maar ook andere thema's zoals Veroudering en Voeding bieden ongetwijfeld mogelijkheden om virologisch onderzoek in deze instelling te verrichten.

Wel is hiervoor een minimale personele formatie en budget noodzakelijk (dat geldt trouwens voor elk vakgebied, al lijken sommigen dit wel eens te vergeten!), zodat de onderzoeker kan doen waarvoor hij of zij is aangesteld en dit is: het doen van onderzoek en niet continue al zijn of haar energie moet stoppen in een soort overlevingsproces om voldoende formatie en budget over te houden om onderzoek te kunnen verrichten. En al is het verwerven van meer budget en personeel via projektsubsidie door $2 \mathrm{e}$ en $3 \mathrm{e}$ geldstroom zeker een teken des tijds, we moeten ons realiseren dat dit steeds 'tijdelijke' projekten betreft en dat er een minimale structurele formatie aanwezig moet zijn om de opgedane kennis te behouden voor de vakgroep en t.z.t. door te geven. 
Wat betreft de toekomstplannen voor de virologie zal het u wellicht duidelijk zijn dat wij onze aandacht willen blijven richten op de rol van virale infecties in chronische processen en in het bijzonder bij het ontstaan van vaatschade.

Het belang van herpesvirussen in deze ligt voor de hand, maar ook de rol van andere virussen is op termijn nier uit te sluiten. Door aan te sluiten bij het bestaande biomedisch onderzoek in CARIM en in nog verder uit te bouwen samenwerking met klinische vakgroepen willen wij participeren in een multidisciplinaire aanpak van de pathogenese van hart-en vaatziekten.

Aan de samenwerking met vakgebieden zoals celbiologie, farmacologie, fysiologie, biochemie, immunologie en pathologie zullen wij verder werken, zodat uitwisselbaarheid van inzichten, methoden en technieken mogelijk is.

Voor de gezondheidszorg zijn invoering van sensitieve en specifieke technieken voor detectie van virale pathogenen noodzakelijk. Vooral onderzoek naar de rol van virale infecries in chronische ziekteprocessen dient uitgewerkt te worden. Dat deze processen wellicht in de meerderheid der gevallen multifactorieel zijn, makk het probleem voor diagnostiek alleen maar groter. Het zal de kunst zijn om 'onschuldige' passanten te onderscheiden van de ware ziekteveroorzakers (pathogenen). De verwachting is dat het antwoord hierop vanuit de moleculair biologische hoek zal moeten komen. Inzet van dergelijke technieken in de diagnostiek is daarom onontbeerlijk!

De grote vooruitgang in de virologie is in het bijzonder gekomen vanuit de hoek van het fundamentele onderzoek. De geschiedenis leert ons immers dat het vooral fysici, chemici, biologen en andere exakte wetenschappers zijn die aan de basis staan van de mijlpalen in dit vakgebied. Het zou dan ook een foutieve interpretatie van de 
geschiedenis zijn om géén volledig gebruik te maken van de kennis van deze fundamentele onderzoekers om de virologische vragen te beantwoorden. De nieuwe virologische diagnostiek zou moeten ontstaan in een multidisciplinair teamverband van basisonderzoekers en medici die elk vanuit hun eigen discipline het probleem benaderen.

Voor de ontwikkeling van nieuwe merhoden en technieken dient er in de begroting (financiële) ruimte gecreëerd te worden, anders is deze essentiële taak van een academisch virologisch laboratorium niet te realiseren.

Ook zou ik van de gelegenheid gebruik willen maken om een vergaande samenwerking voor de virologische diagnostiek in de regio Zuid-Limburg te bepleiten. Immers door schaalvergroting, gekoppeld aan een intensieve samenwerking tussen ziekenhuizen, gezondheidscentra en huisartsenpraktijken in de regio kan de kwaliteir, de dienstverlening en de efficiëntie verbeterd worden.

Voor het onderwijs aan de medische faculteit is het van belang dat de aankomende medicus inzicht verwerf in het mechanisme van virale infecties en uiteraard van de wijze waarop het lichaam hierop reageert. Dus ook hier ligt het accent op multidisciplinaire aanpak van het probleem, hetgeen gezien de grondbeginselen van ons onderwijssysteem gegarandeerd zou moeten zijn. Wat echter m.i. verder uitgewerkt zou moeten worden is de uitbouw van de basisvakken in het curriculum die met het oog op nieuwe technieken voor detecrie van virale pathogenen noodzakelijk is.

Wat het onderwijs betreft zou ik van de gelegenheid gebruik willen maken om ook een enkel woord te zeggen over het grensoverschrijdende onderwijs samen met het Limburgs Universitair Centrum in Diepenbeek (België). Het laatste jaar wordt in de pers zowel aan 
Nederlandse als aan Belgische zijde gewag gemaakt van plannen voor vergaande samenwerking (zelfs dat we één universiteit zouden worden, wordt wel eens geopperd).

Daar ik sinds vorig jaar zelf betrokken ben bij het virologie onderwijs aan de medische faculteit van het Limburgs Universitair Centrum (L.U.C.) ben ik erg benieuwd war 'politiek Nederland en Vlaanderen' ervan terecht zullen brengen, maar al liggen Den Haag en Brussel ver uit elkaar, een intensieve samenwerking of zelfs een samengaan van beide instellingen op termijn biedt vele voordelen; daarvan ben ik rotsvast overtuigd!

Hopelijk lukt dit ambirieuze plan!

\section{Woord van dank}

Het is de gewoonte om aan het eind van een inaugurale rede een woord van dank te richten tot diegenen die hebben bijgedragen aan de totstandkoming van deze benoeming.

In de eerste plaats wil ik het Faculteitsbestuur van de Faculteit der Geneeskunde te Maastricht en de benoemingscommissie bedanken voor het in mij gestelde vertrouwen. I $\mathrm{k}$ beschouw het als een hele eer om deze functie van hoogleraar in de virologie als eerste in Maastricht te mogen vervullen. Ik zal zeker mijn best doen om het in mij gestelde vertrouwen niet te beschamen.

De Raad van Bestuur van het Academisch Ziekenhuis Maastricht wil ik bedanken voor de steun die ik steeds heb mogen ontvangen. De wijze waarop de contacten in de afgelopen jaren verliepen, vond ik bijzonder pretrig en stimulerend. 
Het samengaan van de facultaire vakgroep en de ziekenhuisafdeling heb ik als bijzonder waardevol ervaren; immers op deze wijze komen alle aspecten van her vakgebied: onderzoek, onderwijs en gezondheidszorg, aan bod. Aan de verdere integratie van beide afdelingen zal ik blijven werken.

De basis van mijn virologische opleiding ligt bij de Rijksuniversiteit Leiden bij Prof.Dr. J.D. Verlinde, waar mijn leermeester uit mijn Maastrichtse periode, Prof.Dr. C.P.A. van Boven is heengegaan - we lossen elkaar dus af, zij het dat hij zich bezighoudt met de grote beestjes (de bacteriën) en ik het bij de kleintjes (de virussen) houden zal. De discussies over het vak waren voor mij zeer leerrijk en verhelderend.

Beste Cees, je was een bijna klassiek voorbeeld van hoe colleges gegeven dienen te worden - maar dat kon niet in Maastricht; Leiden zal er nu wel bij varen ...

Maar bovenal heb ik je tolerante houding in menig debat gewaardeerd en van je brede belezenheid op het vakgebied heb ik vaak genoten evenals van de vrijheid die ik bij jou mocht ervaren om de virologie uit te bouwen.

De basis van mijn huidige werk ligt nu in de vakgroep/afdeling Medische Microbiologie te Maastricht. De groep wordt gekenmerkt door vele mensen van uiteenlopende pluimage.

De stafleden van de vakgroep/afdeling Medische Microbiologie wil ik bedanken voor de wijze waarop wij de afgelopen jaren hebben samengewerkt. Onze vele vergaderingen zie ik als het proces van groei rot één afdeling, waarin zowel diagnostiek, als onderzoek en onderwijs, en dit zowel op het gebied van de bacteriologie als de virologie tot hun recht komen. 
Eén van de personen die ik in het bijzonder naar voren wil halen, is Dr. Ellen Stobberingh, mijn compagnon op de bacteriologie, waarmee ik sinds vele jaren samenwerk. Haar grore, onvermoeibare inzet en aandacht voor elkeen heb ik zeer gewaardeerd. Ik hoop dat onze samenwerking in de toekomst ook zó blijven mag.

Prof.Dr. Rietje van Dam-Mieras, waarmee ik een stukje multidisciplinair onderzoek op het grensvlak tussen virologie en biochemie heb opgezet, wil ik bedanken. De zeer prettige en vruchtbare samenwerking, de werkgesprekken die wij samen met Puck Muller en virologie medewerkers, elk vanuit eigen achtergrond voerden, heb ik als zeer positief ervaren en ik hoop hier nog lang mee door te kunnen gaan. Zo onrdekken we samen de rol van virussen bij het ontstaan van vaatwandschade, hoop ik.

I $\mathrm{k}$ wil veel mensen van onze vakgroep/afdeling bedanken, maar enkele medewerkers 'van het eerste uur' wil ik hierbij speciaal vernoemen. Het zijn mensen waar ik reeds meer dan 15 jaar mee samenwerk en op wie ik altijd rekenen kan: het zijn Fia Claus, Gert Grauls en Wil Mullers. Ik dank jullie en hoop dat ik nog vele jaren op deze wijze met jullie mag samenwerken.

Ook Drs. Frans Stals, waarmee ik reeds lange rijd samenwerk en die ik heb zien groeien van student tot medisch viroloog wil ik danken voor de samenwerking. Zijn vaak ontwapenend enthousiasme en inzer voor de virologie heb ik zeer gewaardeerd en ik hoop dat hij verder groeien mag in dit boeiende vak!

Tenslotte wil ik enkele personen, die mij van zéér nabij meemaken, hier vermelden. Dit zijn in de eerste plaats mijn ouders, die ik 
oprecht danken wil. Immers zij zijn diegenen die mij steeds gestimuleerd hebben vanaf het prille begin om een eigen loopbaan uit te bouwen.

Uiteraard ben ik zeer veel dank verschuldigd aan Wouter die mij de ruimte en de mogelijkheden gegeven heeft om zoveel energie in mijn vak te sroppen (hetgeen uiteindelijk geleid heeft tot deze benoeming). Zonder zijn steun was dit niet mogelijk geweest!

Mijn kinderen, Stijn, Klaas en Veerle, wil ik ook even in de bloemetjes zetten, alhoewel ik weet dat zij dat liever niet willen. Het was wellicht niet altijd even prettig om een steeds 'drukke' moeder te hebben, maar één ding is zeker! Jullie zorgden voor het evenwicht tussen werk en thuis ... en dat is goed voor een mens!

Ik dank u allen voor uw aandacht.

Ik heb gezegd. 


\section{Referenties}

Bruggeman, C.A. en M.C.E. van Dam-Mieras. The possible role of cytomegalovirus in atherogenesis. Progress in Medical Virology (1991); 38: 1-26.

Bruggeman, C.A. Cytomegalovirus and latency: an overview. Virchows Archiv. B Cell Pathol. (1993); 64: 325-333.

Collier, L., en J. Oxford. Human Virology. Oxford University Press (1993).

Everdingen, J.J.E. van. Beesten van mensen. Microben en macroben als intieme vijanden. Deel I: Beesten door de eeuwen heen. Deel II: In strijd met het beest. Uitg. Belvèdère, Overveen (1992).

Fabricant, C.G., Fabricant, J., Litrenta, M.M., en C.R. Minick. Virus-induced atherosclerosis. J. Exp. Med. (1978); 148: 335340.

Fettner, A.G. The Science of viruses. G.W. Morrow, New York (1990).

Fields, B.N., en D.M. Knipe. Fundamental Virology. Raven Press, New York (1993).

Gibbons, A. Where are new diseases born? Science (1993); 261: 680681 . 


\section{VIRUS - MENS}

Grattan, M.T., Moreno-Cabral, C.E., Starnes, V.A., Oyer, P.E., Stinson, E.B. en N.E. Shumway. Cytomegalovirus infection is associated with cardiac allograft rejection and atherosclerosis. J.A.M.A. (1989); 261: 3561-3566.

Helvoort, T. van. Research styles in virus studies in the twentieth century: controversies and the formation of consensus. PhD Thesis, Rijksuniversiteit Limburg, Maastricht (1993).

Hendrix, M.G.R., Dormans, P.H.J., Kitslaar, P., Bosman, F., en C.A. Bruggeman. The presence of cytomegalovirus nucleic acids in arterial walls of atherosclerotic and nonatherosclerotic patients. Am. J. Pathol. (1989); 134: 1151-1157.

Henig, R.M. A dancing matrix. Voyages along the viral frontiers. (1993). A.A. Knopf, New York.

Lemström, K.B., Bruning, J.H., Bruggeman, C.A., Laurenschlager, I.T., en P.J. Häyry. Cytomegalovirus infection enhances smooth muscle cell proliferation and intimal thickening of rat aortic allografts. J. Clin. Invest. (1993); 92: 549-558.

Mims, C.A. The origin of major human infections and the crucial role of person-to-person spread. Epidemiol. Infecr. (1991); 106 : 423-433.

Monath, T.P. Yellow fever and dengue - the interactions of virus, vector and host in the re-emergence of epidemic disease. Semin. Virology (1994); 5: 133-145. 
Murphy, F.A., en N. Nathanson. The emergence of new virus diseases: an overview. Sem. in Virology (1994); 5: 87-102.

Murphy, F.A. New, emerging and reemerging infectious diseases. Advances in Virus Research (1994); 43: 1-34.

Stevens, J.G. Overview of herpesvirus latency. Semin. Virology. (1994); 5: $191-196$.

Visser, I.K.G. Morbillivirus infections in seals, dolphins and porpoises. PhD Thesis, Rijksuniversiteit Utreche (1993).

Wenzel, R.P. New Hantavirus infection in North America. New Engl. J. Med. (1994); 330: 1004-1005.

Wilterdink, J.B. Medische Virologie. Bohn, Stafleu \& van Loghum, Houten (1992). 
Maar mocht gij eens, uw werk voldaan, den blijden aest zien binnengaan, en zuchten: Die den arrebeid mij zoet maakt. u zij dank gezeid!

G. Gezelle (1830-1899) 